\title{
AN EXPERIMENTAL STUDY OF RECOVERABLE PRODUCTS FROM WASTE TIRE PYROLYSIS
}

\author{
OZCAN H.K. ${ }^{*}$ \\ ONGEN A. \\ PANGALIYEV Y.
}

Received: 26/01/2015

Accepted: $15 / 03 / 2016$

Available online: $23 / 06 / 2016$

\author{
Istanbul University, Engineering Faculty \\ Department of Environmental Engineering \\ 34320 Avcilar, Istanbul-Turkey
}

\begin{abstract}
In this study, potential of useful products recovery was investigated from waste tires that completed the physical life by virtue of pyrolysis process. Disposal of waste tires, which is one of the global environmental problems, continues the presence thereof as a serious problem, especially in developed countries. Pyrolysis and gasification processes stand out due to making possible the disposal of waste tires and obtaining products that can be employed in energy recovery. Pyrolysis experiments were carried out in a fixed-bed-reactor with cyclone separator at various temperatures $\left(300{ }^{\circ} \mathrm{C}, 400{ }^{\circ} \mathrm{C}, 500{ }^{\circ} \mathrm{C}, 600{ }^{\circ} \mathrm{C}\right.$ and $700{ }^{\circ} \mathrm{C}$ ) and nitrogen, employed as agent gas, was given batch and continuously during the process. In the study, the calorific values of the liquid and solid pyrolysis products were determined as $9117 \mathrm{kcal} \mathrm{m}^{-3}$ and $8710 \mathrm{kcal} \mathrm{kg}^{-1}$ respectively. When the results of the experimental studies were evaluated, synthesis gas rich in $\mathrm{CH}_{4}$ and $\mathrm{H}_{2}$ with a high calorific value of $4180 \mathrm{kcal} \mathrm{m}^{-3}$ was achieved.
\end{abstract}

Keywords: waste to energy, waste derived fuel (WDF), thermal processes

\section{Introduction}

Since tires cannot break down in the nature on their own, they lead to severe environmental problems in case that they are not properly eliminated. Tires are the products of complex high technology and manufactured from a wide spectrum of materials and are made up of various components (Terry et al., 2004). Almost $70-80 \%$ of the tires are made up of carbonated materials (Alkhatib et al., 2015; Hita et al., 2016) and potentially; these carbonated components can be recycled through thermochemical methods.

Annually, almost 1.4 billion tires are sold worldwide and almost the same numbers of tires are discarded (ETRMA, 2011). Approximately 3.4 and 4.6 million tons of discarded tires are estimated to be annually produced in Europe and the USA, respectively (Williams, 2013). The major methods used in waste tire management differ by according to economic costs and industrial usage (Rosendorfova et al., 1998; Koçak and Alpaslan, 2011). Tires have $6000 \mathrm{kcal} \mathrm{kg}^{-1}$ energy value and this figure equals to a high quality coal. For this reason, waste tires can be used as energy sources in cement kilns or in industrial establishments with similar burning units (Elbaba et al., 2010). Additionally, a wide range of application area of the solid and liquid products obtained from the waste tires pyrolysis increases the interest in recycling methods (Ahoor and Zandi-Atashbar, 2014). Gases having high level of calorific value acquired at the end of pyrolysis are used in obtaining energy. Liquid gases, however, can be used as fuels in burning units (Williams, 2002). Char, which is obtained following pyrolysis, is used as active carbon or carbon black (Xiao et al., 2008; Li et al., 2010). 
In general, pyrolysis process starts at between $350-550^{\circ} \mathrm{C}$ and can increase up to $700^{\circ} \mathrm{C}$. Rubber pyrolysis procedures are generally performed between $250-500{ }^{\circ} \mathrm{C}$, but some studies report that it might be up to $900{ }^{\circ} \mathrm{C}$ (Prakash and Karunaithi, 2008). Reactor type plays an important role in pyrolysis procedure. Reactor quality does not only determine the quality and quantity of the products that will be obtained but also the cost of the procedure. Mainly fixed and fluidized-bed reactors are preferred in pyrolysis procedure. Pyrolysis can be applied to raw materials such as coal and biomass, and is also an energy conversion process for solid wastes with highly varying quantities and qualities acquired from different sources (Bridgwater, 2003).

There are various studies conducted on pyrolysis in literature. While these studies particularly focus on gasification of coal (Lee et al., 1998; Shackley et al., 2006), a good number of studies on gasification and pyrolysis of waste tires and different materials is also available (Donatelli et al., 2010; Rincon and Gomez 2012). When the studies performed on waste tires are examined, it is seen that authors generally investigated pyrolysis conditions (Gonzalez et al,. 2001; Leung et al., 2002; Oyedun et al,. 2012) and obtaining recyclable pyrolysis products (Helleura et al., 2001; Diez et al., 2003; Laresgoiti et al., 2004; Shah et al., 2009). This study investigates the probability of obtaining product and products with economic value from the end-of-life tires using pyrolysis method within the scope of sustainable waste management. In pyrolysis experiments, fixed bed steel reactors with cyclone separator were used, and the impact of different experimental conditions on solid, liquid and gas products was investigated.

\section{Materials and Method}

In this study, end-of-life tires and tires classified as waste upon the removal from the cars were used as raw material. Pyrolysis experiments were conducted in steel reactor with cyclone separator and fixed bed (Figure 1). The reactor which was used in the experiments is a stainless steel with vertical shape and is 50 $\mathrm{cm}$ in length and $7 \mathrm{~cm}$ in diameter. Heat requirement of the system was met indirectly via ceramic resistance. Pure graphite and/or graphite-lead helical gaskets were used to prevent gas leak.

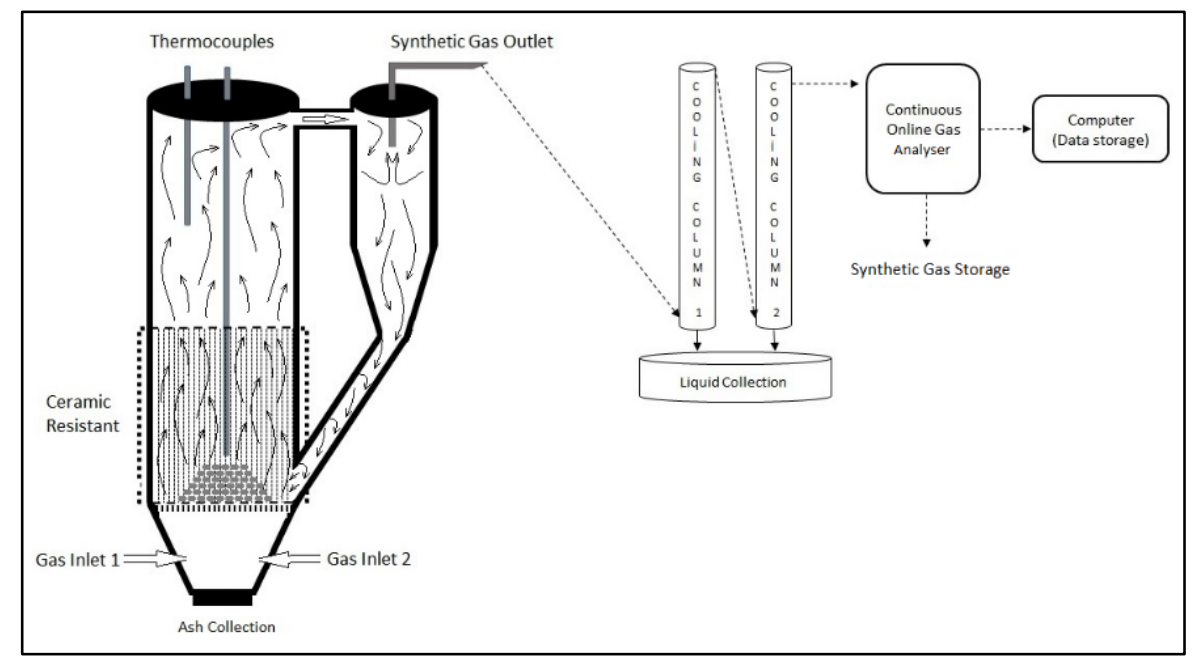

Figure 1. Schematic view of experimental setup

Two different pyrolysis procedures, continuous $\mathrm{N}_{2}$ and intermittent $\mathrm{N}_{2}$ were performed during the study. The pyrolysis procedure in which $\mathrm{N}_{2}$ (continuous) was used as operating gas with 1 I min $^{-1}$ flow was conducted at $300,400,500,600$ and $700{ }^{\circ} \mathrm{C}$. In the second part of the study, $\mathrm{N}_{2}$ gas was used at the beginning of the experiment until $\mathrm{O}_{2}$ was removed from the reactor. Then $\mathrm{N}_{2}$ gas entry into the system was halted. This procedure, which is called intermittent procedure, was conducted at 400, 500, 600 and $700^{\circ} \mathrm{C}$ separately. Thus, we were able to investigate the possible impact of nitrogen gas creating pressure within the system on the generation of pyrolysis products. The pyrolysis procedures conducted with 
continuous $\mathrm{N}_{2}$ were coded with " $\mathrm{E}$ " letter, and those conducted with intermittent $\mathrm{N}_{2}$ were coded with " $\mathrm{Z}$ " letter. Experimental conditions of the trials are given in Table 1.

\subsection{Analytical procedure}

Synthetic gas measurements were performed with ABB-AO2020 model continuous gas analyser. $\mathrm{CO}, \mathrm{CO}_{2}$, $\mathrm{H}_{2}, \mathrm{CH}_{4}$, and $\mathrm{O}_{2}$ amounts within the synthetic gases that were generated during pyrolysis process were measured as volumetric percentage. Elemental analyses of the raw waste tire samples used in the study and the solid and liquid products obtained the end of the experiments were performed. $\mathrm{C}, \mathrm{H}, \mathrm{N}$ and $\mathrm{S}$ amounts of the samples were determined through Truspec CHN-S elemental analysis. Calorific value of liquid products was analyzed with LECO AC500 bomb calorimeter. SEM imaging was performed with FEI Quanta 450 FEG-EDS model SEM-EDS device. Humidity content, ash content, burning loss and solid material content experiments were carried out in order to determine the physical and chemical properties of the waste rubber samples used in the experiments. These experiments were carried out according to Standard Methods. (SM 2540 B; SM2540 E). Approximate calorific values of producer gases were calculated according to $\mathrm{H}_{2}, \mathrm{CO}$ and $\mathrm{CH}_{4}$ volumetric percentages (Ongen et al., 2014; Bossel 2003; Pangaliyev 2014) determined by AO2020 online gas analyzer.

Table 1. Experimental conditions

\begin{tabular}{cccccc}
\hline Experiment & Particle Size $(\boldsymbol{\mu m})$ & Sample $(\mathbf{g})$ & Temperature $\left({ }^{\circ} \mathbf{C}\right)$ & Agent & Flow rate $\left(\mathbf{\text { min } ^ { - 1 } )}\right.$ \\
\hline E1 & $500-1000$ & 100 & 300 & $\mathrm{~N}_{2}$ & 1 \\
\hline E2 & $500-1000$ & 100 & 400 & $\mathrm{~N}_{2}$ & 1 \\
\hline E3 & $500-1000$ & 100 & 500 & $\mathrm{~N}_{2}$ & 1 \\
\hline E4 & $500-1000$ & 100 & 600 & $\mathrm{~N}_{2}$ & 1 \\
\hline E5 & $500-1000$ & 100 & 700 & $\mathrm{~N}_{2}$ & 1 \\
\hline Z1 & $500-1000$ & 100 & 400 & - & - \\
\hline Z2 & $500-1000$ & 100 & 500 & - & - \\
\hline Z3 & $500-1000$ & 100 & 600 & - & - \\
\hline Z4 & $500-1000$ & 100 & 700 & - & - \\
\hline
\end{tabular}

\section{Results and Discussion}

In the first part of the study, we aimed to determine some physical and chemical properties of the waste tire to be used in the study. For this purpose, elemental analysis was performed, and humidity percentage, ash amount, burning loss, and solid material contents were ascertained. The results obtained from the elemental analysis of waste tire sample are given in Table 2.

Table 2. Elemental and proximate analysis results of raw waste tire

\begin{tabular}{cccccc}
\hline \multicolumn{7}{c}{ Ultimate Analysis, \%mass } \\
\hline C & H & N & S & O & Reference \\
\hline 80.4 & 8.7 & 0.3 & 1.6 & $9^{*}$ & Present study \\
\hline 82.8 & 7.6 & 0.5 & 1.3 & 4.5 & Dai et al., 2001 \\
\hline 86.7 & 8.1 & 0.4 & \multicolumn{1}{c}{1.4} & 1.3 & Gonzalez et al., 2001 \\
\hline \multicolumn{7}{c}{ Combustion loss } & Solid matter \\
\hline Moisture & Ash & \multicolumn{2}{c}{ Comate Analysis, \%mass } \\
\hline 0.5 & 33.15 & \multicolumn{2}{c}{66.85} & 99.5 & Present study \\
\hline
\end{tabular}

*calculated by difference

The fuel to be used for pyrolysis has a considerable effect on the efficiency of the product to be obtained. Gaseous and liquid products with high calorific value are mainly obtained from the fuels rich in carbon and hydrogen. The result of the elemental analysis given in Table 2 indicated that the sample contained $80.4 \%$ carbon and $8.7 \%$ hydrogen. These values are consistent with the literature, and show that the samples used in the study are suitable fuels for pyrolysis. 


\subsection{Synthesis Gas Analysis Results}

All synthesis gas values obtained in the experiments (E1, E2, E3, E4, E5) in which $\mathrm{N}_{2}$ was continuously fed are given in Figure 2. It was found out that $\mathrm{CH}_{4}$ and $\mathrm{H}_{2}$ gas percentages within the synthetic gas were low in the experiments conducted at 300 and $400{ }^{\circ} \mathrm{C}$. It was observed that $\mathrm{CO}$ gas was not formed due to low temperature and that partial burning did not take place in the absence of oxygen during the experiments. Pyrolysis is also reported to be one of the reliable scenarios for the energy conversion from waste tires that produces syngas with very low $\mathrm{CO}$ and $\mathrm{CO}_{2}$. During the experiments carried out at 600 and $700{ }^{\circ} \mathrm{C}$ that $\mathrm{CH}_{4}$ and $\mathrm{H}_{2}$ gas percentages within the synthetic gas are found higher in comparison to the experiments conducted at lower temperatures $\left(400,500{ }^{\circ} \mathrm{C}\right.$ ) (Figure 2). The highest $\mathrm{CH}_{4}(17 \%)$ and $\mathrm{H}_{2}$ (11\%) levels were obtained in E5 experiment.
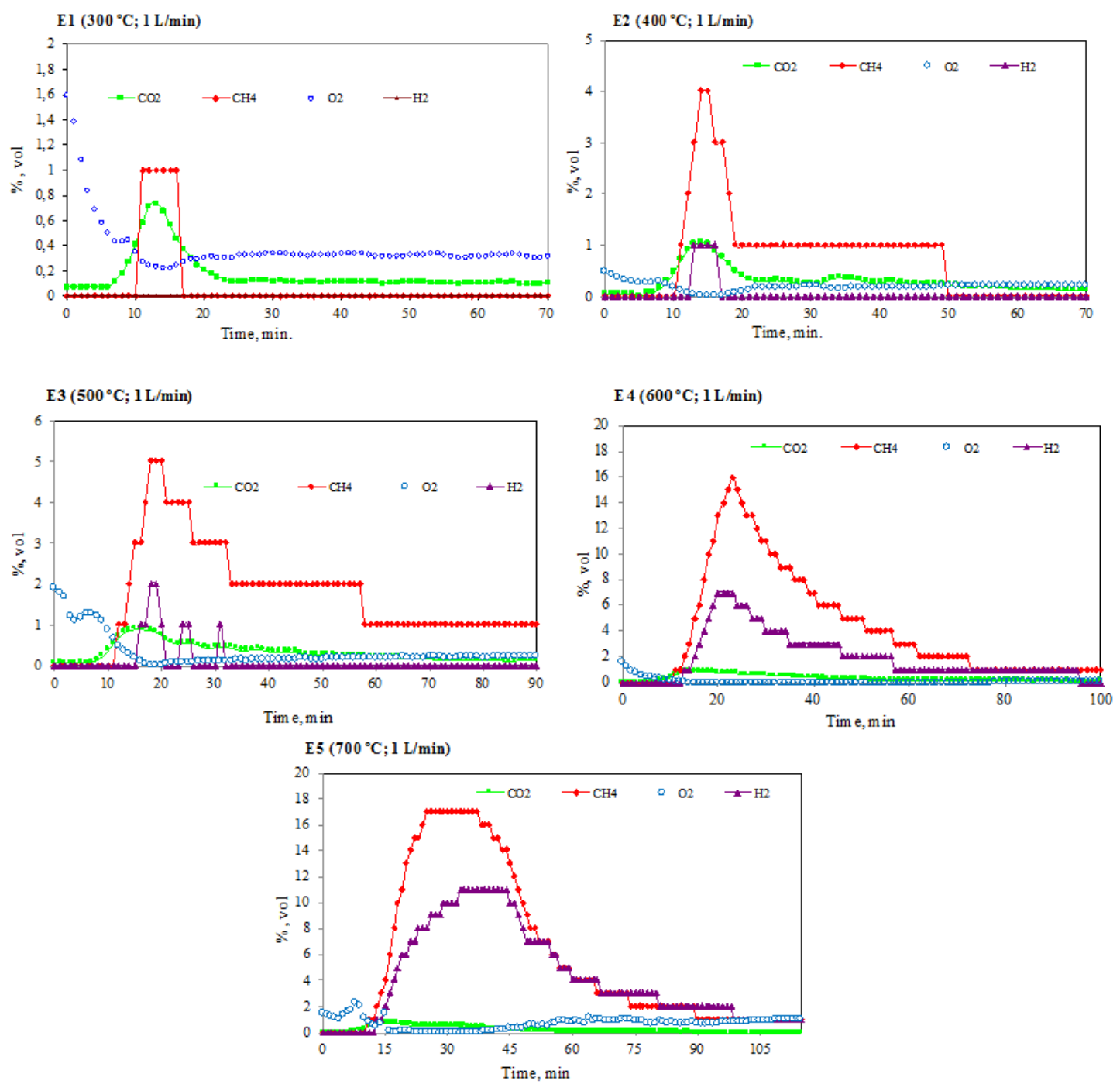

Figure 2. Synthesis gas content of continuous $\mathrm{N}_{2}$ pyrolysis experiments

In the pyrolysis experiments $(\mathrm{Z1}, \mathrm{Z2})$ carried out at 400 and $500{ }^{\circ} \mathrm{C}$ with intermittent $\mathrm{N}_{2}, \mathrm{CH}_{4}$ increased from $12 \%$ to $25 \%$. It was also found out that $\mathrm{H}_{2}$ gas percentage increased from $6 \%$ to $18 \%$ at $400{ }^{\circ} \mathrm{C}$. In the experiments performed at 600 and $700{ }^{\circ} \mathrm{C}(\mathrm{Z3}, \mathrm{Z4})$, it was determined that $\mathrm{CH}_{4}$ and $\mathrm{H}_{2}$ percentages increased considerably in comparison with the experiments conducted at low temperatures $(400$ and $500{ }^{\circ} \mathrm{C}$ ). It was found that in all pyrolysis experiments conducted with intermittent $\mathrm{N}_{2}$, the percentage of $\mathrm{CO}$ gas within synthesis gas is lower compared to $\mathrm{CH}_{4}$ and $\mathrm{H}_{2}$ gases. $\mathrm{CO}$ values observed at the experiments performed with intermittent $\mathrm{N}_{2}$ ranged from $0 \%-2 \%$. Gas conversion performance is expected to go up with the increase in temperature. An increase in pyrolysis temperature increased the yield of gaseous 
products and decreased residue char production. Taking the data given in Figure 2 and Figure 3 into consideration, it was observed that $\mathrm{CH}_{4}$ and $\mathrm{H}_{2}$ gas percentages within synthesis gas obtained from the intermittent $\mathrm{N}_{2}$ pyrolysis experiments were high.
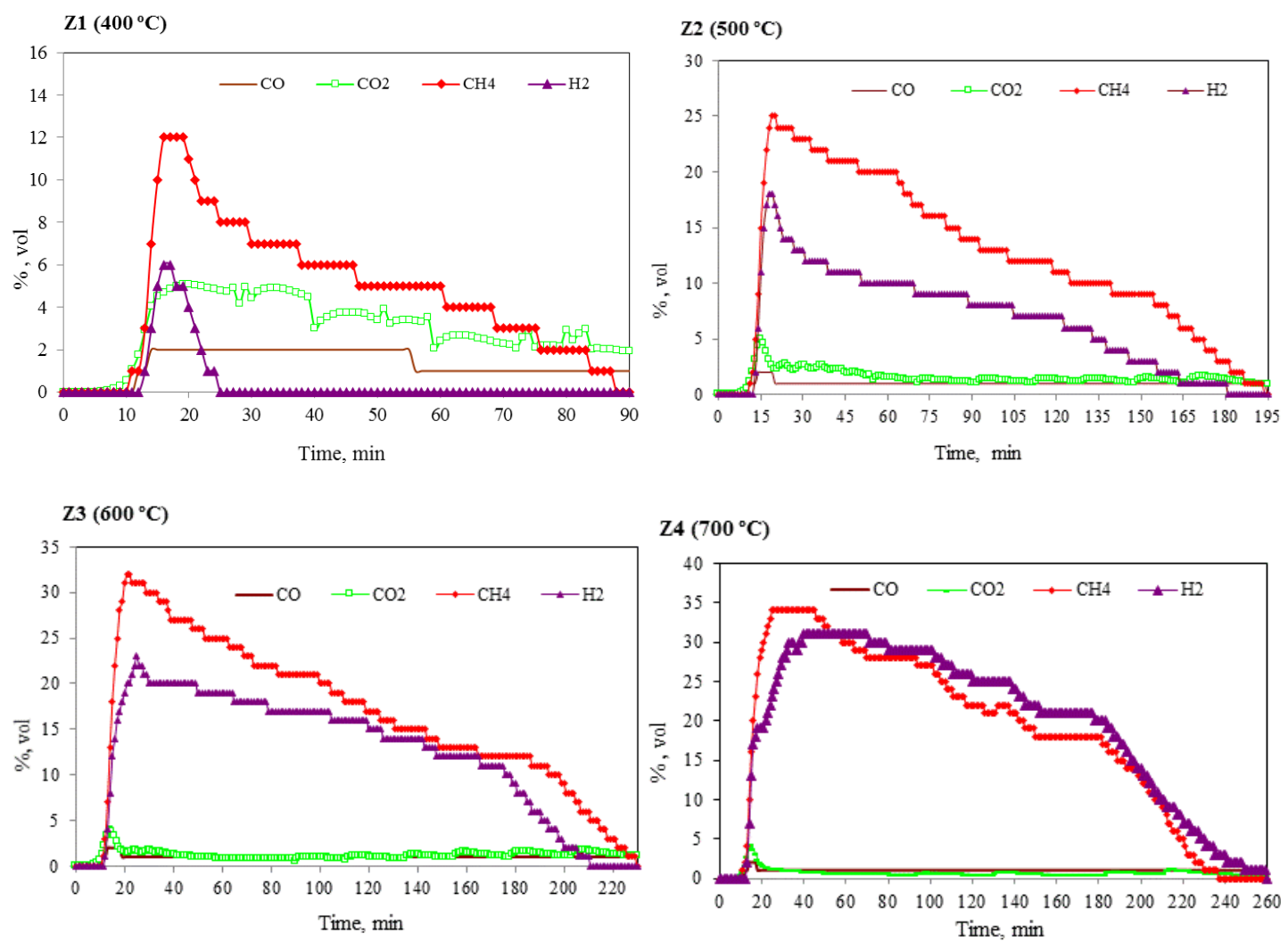

Figure 3. Synthesis gas content of intermittent $\mathrm{N}_{2}$ pyrolysis experiments

For this reason, maximum calorific value $\left(4180 \mathrm{kcal} \mathrm{m}^{-3}\right)$ of the synthetic gas in the experiments conducted with intermittent $\mathrm{N}_{2}$ is higher than the maximum calorific value $\left(1970 \mathrm{kcal} \mathrm{m}^{-3}\right)$ of the synthetic gas in the experiments carried out with continuous $\mathrm{N}_{2}$. At pyrolysis phase, it was observed that continuous $\mathrm{N}_{2}$ presence created a volumetrically limiting effect. Upon generating an environment free-of oxygen, it was seen that cutting $\mathrm{N}_{2}$ entry into the system and increasing reaction temperatures enhanced synthesis gas efficiency. Besides, it was seen that the increase in operating temperature independent from the presence of $\mathrm{N}_{2}$ gas increased $\mathrm{CH}_{4}$ and $\mathrm{H}_{2}$ gas percentages.

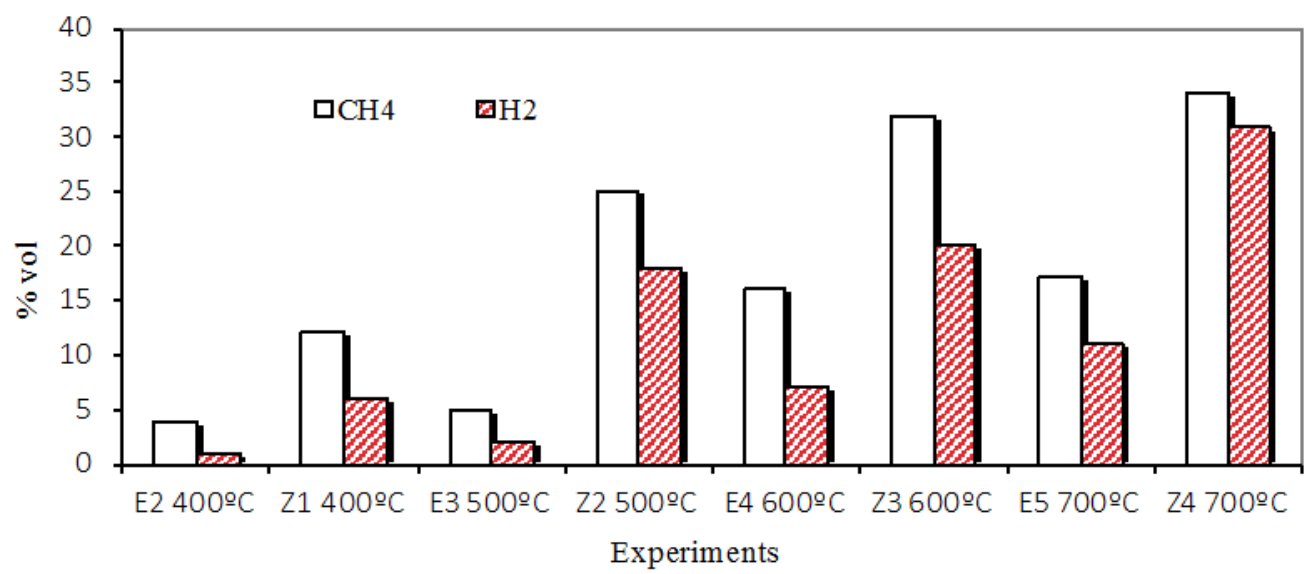

Figure 4. Highest values of $\mathrm{CH}_{4}$ and $\mathrm{H}_{2}$ gases obtained from pyrolysis 
Figure 4 presents the highest values of $\mathrm{CH}_{4}$ and $\mathrm{H}_{2}$ gases obtained as a result of the continuous and intermittent pyrolysis carried at different temperatures. Calorific value of the synthesis gases obtained at the end of the experiments was calculated mathematically. The results obtained indicated that synthesis gases had high calorific value. The synthesis gas with the highest calorific value in pyrolysis experiments was obtained in experiment Z4 with $4180 \mathrm{kcal} \mathrm{m}^{-3}$.

\subsection{Solid and Liquid Product Analysis}

Liquid product (tar) and solid residue (char) collected at the end of pyrolysis experiments are given in Table 3. Elemental analysis of the solid and liquid products obtained as a result of continuous $\mathrm{N}_{2}$ pyrolysis experiments was performed, and their calorific value was calculated. Table 4 represents elemental analysis and calorific value of liquid and solid products. In the study, while $90.2 \mathrm{~g}$ char was acquired in E1 experiment, $45.2 \mathrm{~g}$ char was obtained in $\mathrm{E} 5$. It was detected that carbon content mass of raw waste tire sample was $80.38 \%$, whereas this value was $80.82 \%$ in the pyrolysis performed at $300{ }^{\circ} \mathrm{C}$. It was found that liquid products started to be acquired intensely at $500^{\circ} \mathrm{C}$ and it continued up to $700^{\circ} \mathrm{C}$. If it is desired to properly complete the pyrolysis procedure carried out with the aim of enriching the carbon within the fuel at low temperatures, it should be taken into consideration that reaction time might be quite longer. According to the elemental analysis of the liquid product obtained at the end of the pyrolysis performed with continuous $\mathrm{N}_{2}$, demonstrated that it was found to be made up of a mixture of organic compounds, and contained carbon and hydrogen gases by weight (Table 4).

Table 3. Solid and liquid products obtained from pyrolysis

\begin{tabular}{ccccc}
\hline Experiments & Pyrolysis conditions & Raw waste tire (g) & $\begin{array}{c}\text { Liquid } \\
\text { product (g) }\end{array}$ & Solid products (g) \\
\hline $\mathrm{E} 1$ & continuous $\mathrm{N}_{2}-1 \mathrm{I} \mathrm{min}^{-1} ; 300^{\circ} \mathrm{C}$ & 100 & 0.4 & 90.2 \\
\hline $\mathrm{E} 2$ & continuous $\mathrm{N}_{2}-1 \mathrm{I} \mathrm{min}^{-1} ; 400^{\circ} \mathrm{C}$ & 100 & 5.6 & 77.7 \\
\hline $\mathrm{E} 3$ & continuous $\mathrm{N}_{2}-1 \mathrm{I} \mathrm{min}^{-1} ; 500^{\circ} \mathrm{C}$ & 100 & 6.5 & 67.2 \\
\hline $\mathrm{E} 4$ & continuous $\mathrm{N}_{2}-1 \mathrm{I} \mathrm{min}^{-1} ; 600^{\circ} \mathrm{C}$ & 100 & 1.8 & 52.6 \\
\hline $\mathrm{E} 5$ & continuous $\mathrm{N}_{2}-1 \mathrm{I} \mathrm{min}^{-1} ; 700^{\circ} \mathrm{C}$ & 100 & 21.3 & 45.2 \\
\hline $\mathrm{Z1}$ & intermittent $\mathrm{N}_{2} ; 400^{\circ} \mathrm{C}$ & 100 & 0.5 & 80.9 \\
\hline $\mathrm{Z2}$ & intermittent $\mathrm{N}_{2} ; 500^{\circ} \mathrm{C}$ & 100 & 8.1 & 62.3 \\
\hline $\mathrm{Z3}$ & intermittent $\mathrm{N}_{2} ; 600^{\circ} \mathrm{C}$ & 100 & 5.3 & 53 \\
\hline $\mathrm{Z4}$ & intermittent $\mathrm{N}_{2} ; 700^{\circ} \mathrm{C}$ & 100 & 9.8 & 49.2 \\
\hline
\end{tabular}

As a liquid fuel, diesel fuel has $10256 \mathrm{kcal} \mathrm{kg}^{-1}$ calorific value. Accordingly, the liquid product with 9117 $\mathrm{kcal} \mathrm{kg}^{-1}$ calorific value obtained at $700 \mathrm{C}$ as a result of continuous $\mathrm{N}_{2}$ pyrolysis can be regarded as an alternative fuel quite similar to the diesel fuel. The continuous $N_{2}$ and intermittent $N_{2}$ pyrolysis experiments revealed that liquid product amount obtained in pyrolysis experiments of high temperatures $\left(>600{ }^{\circ} \mathrm{C}\right)$ is higher than the pyrolysis experiments of low temperatures $\left(<600{ }^{\circ} \mathrm{C}\right)$. It was detected that heat increase in the pyrolysis experiments carried out with continuous $\mathrm{N}_{2}$ and intermittent $\mathrm{N}_{2}$ had an influence on the increase in the amount of liquid products (Table 3). When a comparison is made with regard to the calorific value of raw tire, it is observed that particularly mass form became rich in carbon at low temperatures. A relative decrease was observed in calorific values with the addition of the carbon within the fuel into the reactions with increasing heat. However, when all experiments are examined with multiple product perspective, it should not be disregarded that it is possible to benefit from each of the product type (mass, liquid, gas) both as an energy source and raw material. The limitations that arise from the fixed bed reactors used in the experiments are thought to be among the reasons why it is not possible to benefit from the carbon within the fuel in a more efficient way at high temperatures.

Waste tire granules used in our study were imaged with $\times 80, x 500, x 1500$ and $x 2500$ percentage magnification using Scanning Electron Microscope (SEM) in order to monitor the pre and post-pyrolysis changes that occur in the solid product morphologies. 
Table 4. Elemental analysis and calorific value of liquid and solid products from continuous $\mathrm{N}_{2}$ pyrolysis experiments

\begin{tabular}{|c|c|c|c|c|c|}
\hline \multicolumn{6}{|c|}{ Solid products } \\
\hline & \multicolumn{5}{|c|}{ Elemental Analysis, weight \% } \\
\hline & C & $\mathbf{H}$ & $\mathbf{N}$ & $\mathbf{S}$ & Calorific Value $\left(\mathrm{kcal} \mathrm{kg}^{-1}\right)$ \\
\hline Raw Tire & 80.38 & 8.67 & 0.3 & 1.6 & 7883 \\
\hline E1 continuous $\mathrm{N}_{2}-1$ I $\mathrm{min}^{-1} ; 300^{\circ} \mathrm{C}$ & 80.82 & 1.34 & 9.65 & 1.14 & 8710 \\
\hline E2 continuous $\mathrm{N}_{2}-1$ I $\mathrm{min}^{-1} ; 400^{\circ} \mathrm{C}$ & 83.43 & 1.08 & 8.03 & 1.68 & 8254 \\
\hline E3 continuous $\mathrm{N}_{2}-1 \mathrm{I} \mathrm{min}^{-1} ; 500^{\circ} \mathrm{C}$ & 77.85 & 5.51 & 1.28 & 1.92 & 7729 \\
\hline E4 continuous $\mathrm{N}_{2}-1 \mathrm{I} \mathrm{min}^{-1} ; 600^{\circ} \mathrm{C}$ & 77.74 & 2.12 & 1.39 & 2.07 & 7363 \\
\hline E5 continuous $\mathrm{N}_{2}-1 \mathrm{I} \mathrm{min}^{-1} ; 700^{\circ} \mathrm{C}$ & 74.53 & 4.27 & 1.66 & 1.95 & 6801 \\
\hline \multicolumn{6}{|c|}{ Liquid products } \\
\hline & \multicolumn{5}{|c|}{ Elemental Analysis, weight \% } \\
\hline & C & $\mathbf{H}$ & $\mathbf{N}$ & $\mathbf{S}$ & Calorific Value $\left(\mathrm{kcal} \mathrm{kg}^{-1}\right)$ \\
\hline E3 continuous $\mathrm{N}_{2}-1 / \mathrm{min}^{-1} ; 500^{\circ} \mathrm{C}$ & 64.61 & 10.08 & 0.30 & 0.72 & 9117 \\
\hline E4 continuous $\mathrm{N}_{2}-1 / \mathrm{min}^{-1} ; 600^{\circ} \mathrm{C}$ & 66.41 & 9.9 & 0.40 & 0.39 & 8751 \\
\hline E5 continuous $\mathrm{N}_{2}-1 \mathrm{I} \mathrm{min}^{-1} ; 700^{\circ} \mathrm{C}$ & 76.70 & 4.81 & 0.29 & 0.23 & 8140 \\
\hline
\end{tabular}

Figure 5 presents the relevant data. SEM analysis indicated that pore size of the mass products obtained from continuous $\mathrm{N}_{2}$ pyrolysis experiments (E5) of high temperatures $\left(700{ }^{\circ} \mathrm{C}\right)$ increased with heat. Expansion in pore structure shows that solid products can be regarded as absorbent materials.

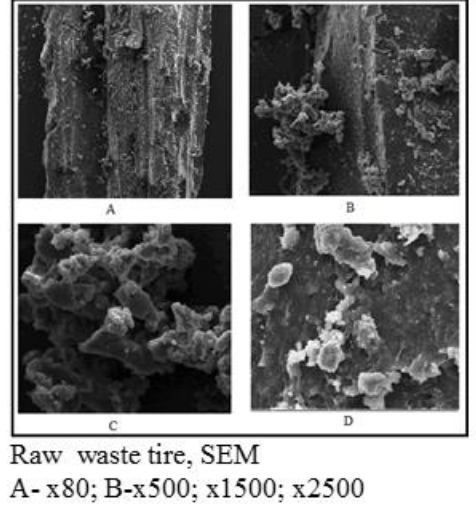

Figure 5. SEM micrographs of raw tire and post pyrolysis materials

\section{Conclusions}

In this study, for the production and the characterization of the pyrolysis products, fixed-bed pyrolysis of waste tires was carried out. The results led to the following conclusions:

1. It was observed that liquid products began to be acquired intensely at $500{ }^{\circ} \mathrm{C}$ and continued to be acquired intensely up to $700{ }^{\circ} \mathrm{C}$. The calorific values of the liquid products obtained varied between 8140 - $9117 \mathrm{kcal} \mathrm{kg}^{-1}$. $9117 \mathrm{kcal} \mathrm{kg}^{-1}$ degree obtained in $\mathrm{E} 3$, where the highest calorific value was achieved, points out that this product can be used as an alternative energy source.

2. It was found that $\mathrm{N}_{2}$ intermittent experiments pyrolysis lasted longer than $\mathrm{N}_{2}$ continuous pyrolysis experiments. In pyrolysis experiments it was found that solid product amount decreases with temperature increase. While $90.2 \mathrm{~g}$ solid debris was obtained at $300{ }^{\circ} \mathrm{C}$, it was observed that $45.2 \mathrm{~g}$ char left at $700^{\circ} \mathrm{C}$ (Table 3). This case indicates that organic material moves away from the system with a higher degree as temperature increases. 
3. Solid product obtained in the pyrolysis procedure carried out at $300{ }^{\circ} \mathrm{C}$, had $8710 \mathrm{kcal} \mathrm{kg}^{-1}$ calorific value. Considering that calorific value of the anthracite coal, one of the fossil fuels extensively used, is around $7700 \mathrm{kcal} \mathrm{kg}^{-1}$ (TMMOB, 2010), this calorific value shows that a solid fuel with a higher energy than anthracite coal was obtained. It can be regarded that this calorific value might be increased to higher degrees with the extension of reaction time.

4. In addition to obtaining recyclable products with the pyrolysis of waste tires, it is also possible to achieve environmental gains. Management of waste tires with calorific methods ensure waste minimization in terms of both volume and mass to a great degree. At the end of the pyrolysis experiment performed at $700{ }^{\circ} \mathrm{C}$ (E5), it was seen that waste tires shrank 50-55 \% in mass, and $55-60 \%$ in volume (Table 3 ). It is believed that it will solve the space problem in storing the waste tires substantially.

This study provides valuable findings at selected experimental conditions for energy recovery, indicating that waste tires can be used as alternative energy sources. It is possible to achieve economic gain with the elimination of an environmental problem.

\section{Acknowledgements}

This study, a part of Msc thesis entitled "Derivation of recoverable products from waste tire by pyrolysis/gasification" which conducted at Istanbul University Natural Science Institute. This work was supported by the Research Fund of the Istanbul University (Project number: 57007)

\section{References}

Ahoor A.H. and Zandi-Atashbar N. (2014), Fuel production based on catalytic pyrolysis of waste tires as an optimized model, Energy Conversation Management, 87, 653-669.

Alkhatib R., Loubar K., Awad S., Mounif E. and Tazerout M. (2015), Effect of heating power on the scrap tires pyrolysis derived oil, Journal of Analytical and Applied Pyrolysis, 116, 10-17.

Bossel U. (2003), Well-to-Wheel Studies, Heating Values, and the Energy Conservation Principle, European Fuel Cell Forum, Oberrohrdorf / Switzerland

Bridgwater A.V. (2003), Renewable fuels and chemicals by thermal processing of biomass, Chemical Engineering Journal, 91, 87-102.

Dai X., Yin X., Wu C., Zhang W. and Chen Y. (2001), Pyrolysis of waste tires in a circulating fluidized-bed reactor, Energy, 26, 385-399.

Diez O, Maetinez L.F., Calvo J. and Cara A.M. (2003), Pyrolysis of tires, influence of the final temperature of the process on emissions and the calorific value of the products recovered, Waste Management, 24, 463-469.

Donatelli A., lovanea P. and Molino A. (2010), High energy syngas production by waste tires steam gasification in a rotary kiln pilot plant. Experimental and numerical investigations, Fuel, 89, 2721-2728.

Elbaba I.F., Wu C. and Williams P.T. (2010), Catalytic pyrolysis-gasification of waste tire and tire elastomers for hydrogen production, Energy Fuels, 24, 3928-3935.

ETRMA. (2011) End-of-Life tires management report, A valuable resource with growing potential - 2011 edition, Brussels.

Gonzalez J.F., Encinar J.M. Jose, L., Canito J.L. and Rodriguez J.J. (2001), Pyrolysis of automobile tire waste. Influence of operating variables and kinetics study, Journal of Analytical and Applied Pyrolysis, 58, 667-683.

Helleura R., Popovic N., Ikura M., Stanciulescu M. and Liu D. (2001), Characterization and potential applications of pyrolytic char from ablative pyrolysis of used tires, Journal of Analytical and Applied Pyrolysis, 58, 813-824.

Hita I., Arabiourrutia M., Olazar M., Bilbao J., Arandes J.M. and Castaño P. (2016), Opportunities and barriers for producing high quality fuels from the pyrolysis of scrap tires, Renewable and Sustainable Energy Reviews, 56, 745-759.

Koçak Y. and Alpaslan L. (2011), Potentials use of waste tires in cement and concrete industry 6th International Advanced Technologies Symposium (IATS'11), 2011, Elazig, Turkey 
Laboy-Nieves E.N. (2014), Energy Recovery from Scrap Tires: A Sustainable Option for Small Islands like Puerto Rico, Sustainability, 6, 3105-3121.

Laresgoiti M.F., Caballero B.M., Marco I., Torres A., Cabrero M.A. and Chomon M.J. (2004), Characterization of the liquid products obtained in tire pyrolysis, Journal of Analytical and Applied Pyrolysis, 71, 917-934.

Lee J.M., Kim Y.J. and Kim S.D. (1998), Catalytic coal gasification in an internally circulating fluidized bed reactor with draft tube, Applied Thermal Engineering, 18, 1013-1024.

Leung D.Y.C., Yin X.L., Zhao Z.L., Xu B.Y. and Chen Y. (2002), Pyrolysis of tire powder: influence of operation variables on the composition and yields of gaseous product, Fuel Processing Technology, 79, 141-155.

Li L., Liu S. and Zhu T. (2010), Application of activated carbon derived from scrap tires for adsorption of Rhodamine B, Journal of Environmental Science, 22, 1273-80.

Ongen A., Ozcan H.K. and Arayic A. (2013), An evaluation of tannery industry wastewater treatment sludge gasification by artificial neural network modeling, Journal of Hazardous Materials, 263, 361-366.

Oyedun A., Lam K.L., Fittkau M. and Hui C.W. (2012), Optimization of particle size in waste tire pyrolysis, Fuel, 95, 417-424.

Pangaliyev Y. (2014), Derivation of recoverable products from waste tire by pyrolysis/gasification, Master Thesis, Istanbul University Natural Science Institute.

Prakash N. and Karunanithi T. (2008), Kinetic Modeling in Biomass Pyrolysis - A Review. Journal of Applied Sciences Research, 12, 1627-1636.

Rincon S.L. and Gomez A. (2012), Comparative behaviour of agricultural biomass residues during thermochemical processing, Global NEST Journal, 14, 111-117.

Rosendorfova M., Vybochova I. and Beukering P. (1998), Waste Management and Recycling of Tires in Europe, Institute for Environmental Studies IVM/VU, Amsterdam.

Shackley S., Mander S. and Reichea A. (2006), Public perceptions of underground coal gasification in the United Kingdom, Energy Policy, 34, 3423-3433.

Shah J., Jan M.R. and Mabood F. (2009), Recovery of value-added products from the catalytic pyrolysis of waste tire, Energy Conversation Management, 50, 991-994.

SM 2540 B. (1998), Standard methods for the examination of water and wastewater $20^{\text {th }}$ Edition, Franson.M.H., American Public Health Association, 1998.

SM 2540 E. (1998), Standard Methods For The Examination of Water and Wastewater 20 ${ }^{\text {th }}$ Edition, Franson M.H., American Public Health Association, 1998

Terry A.G. and Hammer C. (2004), Designing Building Products Made With Tires, Contractor's Report to the Board, Integrated Waste Managment Board, California, 2004, USA

TMMOB. (2010), Chambers of Mining Engineers Turkey, Coal Report (in Turkish), 2010

Xiao G., Ni, M-J. Chi, Y. and Cen K-F. (2008), Low-temperature gasification of waste tire in a fluidized bed, Energy Conversation Management, 49, 2078-2082.

Williams P.T. (2013), Pyrolysis of waste tires: a review, Waste Management, 33, 1714-1728. 